\title{
KAI KURIŲ FIZIOLOGINIŲ RODIKLIŲ KITIMO IVERTINIMAS ATSIGAVIMO LAIKOTARPIU PO SUBMAKSIMALAUS FIZINIO KRŪVIO MÉGINIO
}

\author{
Alma Kajënienè $\dot{1}^{1,2}$, Alfonsas Vainoras ${ }^{2}$, Renata Žumbakyte் $\dot{\mathrm{L}}^{1,2,3}$, Kristina Berškiene் $\dot{\mathrm{e}}^{2,3}$ \\ Lietuvos kūno kultūros akademija ${ }^{1}$, Kauno medicinos universitetas ${ }^{2}$, Kauno technologijos universitetas ${ }^{3}$, \\ Kaunas, Lietuva
}

\begin{abstract}
Alma Kajènienė. Kauno medicinos universiteto doktorantė. Kauno medicinos universiteto Kineziologijos ir sporto medicinos katedros asistentė. Mokslinių tyrimų kryptis — sportuojančių asmenų dozuoto fizinio krūvio mėginio atsigavimo laikotarpio fiziologinių rodiklių vertinimas.
\end{abstract}

\section{SANTRAUKA}

Tyrimo tikslas - ištirti krepšininku, futbolininku, nesportuojančiı asmenu (vyru ir moteru) organizmo atsigavimo fiziologiniu rodikliu pokyčio dydžius kiekvienq atsigavimo minute po submaksimalaus fizinio krūvio ir juos palyginti.

Ištirta 270 asmenu: trys vyru (krepšininku (KV), futbolininku (FV) ir nesportuojančiuju (NV)) ir dvi moteru ( krepšininkiu (KM) ir nesportuojančiuju (NM)) grupes.

Norédami nuodugniau išanalizuoti sportininku atsigavimo po dozuoto fizinio krūvio kaita, taikème integralios organizmo reakcijos i fizini krūvì modeli, kuris apima reguliacinès (centrinès nervu sistemos, autonominio, humoralinio valdymo), aprūpinančiosios (kvèpavimo, širdies ir kraujagysliu) ir vykdančiosios (fizinio krūvio metu veikliuju raumenu grupiu) sistemu sqsaja ir ju poreiški krūvio metu. Naudota KMU Kardiologijos institute sukurta automatizuota EKG analizès sistema , Kaunas - Krüvis “, kuri sinchroniškai registruoja ir analizuoja išugdoma raumenu galinguma, arterini kraujo spaudima ir EKG. Atliktas visu tiriamuju kompiuterizuotas veloergometrinis fizinio krūvio mèginys naudojant trumpalaiki provokacini tyrimo protokolq. Sveikos nesportuojančios moterys pradejo krūvi atlikti nuo $50 \mathrm{~W}$ galingumo ir kas minutę ji didino po $25 \mathrm{~W}$ iki submaksimalaus išugdomo $(50+n \times 25 \mathrm{~W})$. Kiti krūvi pradèjo nuo $50 \mathrm{~W}$ galingumo ir kas minute ji didino po $50 \mathrm{~W}$ iki submaksimalaus $(50+n \times 50 \mathrm{~W})$. Atsigavimo laikotarpis registruotas penkias minutes. Vertinti fiziologiniu rodikliu (širdies susitraukimu dažnio (HR), intervalo JT, t. y. (JT), sistolinio arterinio kraujo spaudimo (T), santykinès repoliarizacijos $J T / R R, t . y .(J T / R R)$ ir santykinés pulsinès amplitudès $(S-D)$ / S) pokyčio dydžiai ir seka kiekvienq atsigavimo minutę. Dydžiai S ir HR labiau sietini su reguliacija, $o(S-D)$ / S ir JT - su atskiru organu funkcija ir nusako periferijos atsakq.

Atlikus tyrima padarytos tokios išvados:

1. Skirtingi atsigavimo rodikliai patikimai skiriasi atsigavimo greičiu.

2. Futbolininku, krepšininku, nesportuojančiuju, vyru ir moteru atskiru fiziologiniu procesu atsigavimo greičiai bei ju seka skiriasi.

Raktažodžiai: elektrokardiogramos pokyčiai, krūvis, atsigavimas.

\section{IVADAS}

$\mathrm{D}$ augelis sportinių žaidimų (pvz., krepšinis, futbolas, badmintonas ir kt.) yra intervalinio pobūdžio ir atliekami trumpomis ( $\leq$ šešių sekundžių trukmès) maksimaliomis (submaksimaliomis) pastangomis. Žaidimo veiklą sudaro reliatyviai trumpi ( $\leq 60$ sekundžiu trukmès) ir vidutinio (žemo) intensyvumo atsigavimo laikotarpiai (Glaister, 2005). Kurị laiką organizmas negeba pakartoti anksčiau buvusio krūvio, ir tai padaryti būna i̇manoma tik po tam tikro atsigavimo laikotarpio (Wasserman et al., 1998; Gocentas, Andziulis, 2004). Atsigavimo trukmè ir pobūdis priklauso nuo patirto fizinio krūvio ypatumų, krūvio modelio bei tiriamojo treniruotumo, o atsigavimo kokybė yra skirtinga (Gocentas, Andziulis, 2004). Daugelis fiziologiniu reakcijų, svarbių vertinant sportininko būseną, atsiskleidžia šiuo laikotarpiu. Nors šis etapas svarbus vertinant sportininko funkcinę būklę, formalūs atsigavimo kaitos rodikliai pasaulinèje literatūroje mažai na- 
Lentelè. Nagrinètų grupių duomenys

\begin{tabular}{|c|c|c|c|c|c|c|}
\hline Grupè & $\begin{array}{l}\text { Imties } \\
\text { dydis }\end{array}$ & Amžius, m. & Ūgis, $\mathrm{cm}$ & Kūno svoris, $\mathrm{kg}$ & $\begin{array}{l}\text { Santykinis atlikto } \\
\text { darbo galingumas, } \\
\mathrm{W} / \mathrm{kg}\end{array}$ & Sportinis stažas, $\mathrm{m}$. \\
\hline Vyrai krepšininkai (KV) & 113 & $19,01 \pm 3,75$ & $194,99 \pm 8,01$ & $85,10 \pm 11,33$ & $2,73 \pm 0,43$ & $9,58 \pm 3,366$ \\
\hline Vyrai futbolininkai (FV) & 55 & $22,49 \pm 4,43$ & $183,02 \pm 6,6$ & $78,00 \pm 7,55$ & $2,97 \pm 0,45^{\star}$ & $13,84 \pm 4,90$ \\
\hline Nesportuojantys vyrai (NV) & 32 & $24,47 \pm 7,7$ & $178,25 \pm 6,69$ & $76,40 \pm 15,07$ & $2,13 \pm 0,66$ & 0 \\
\hline Moterys krepšininkès (KM) & 38 & $22,16 \pm 5,44$ & $180,61 \pm 6,57$ & $71,89 \pm 8,2$ & $2,82 \pm 0,62$ & $12,15 \pm 6,79$ \\
\hline $\begin{array}{l}\text { Nesportuojančios moterys } \\
\text { (NM) }\end{array}$ & 32 & $25,91 \pm 6,48$ & $167,81 \pm 6,12$ & $61,23 \pm 11,09$ & $1,94 \pm 0,44$ & 0 \\
\hline
\end{tabular}

Pastaba. Duomenys pateikti $\mathrm{M} \pm \mathrm{SD}$.

grinėti. Organizmo funkcinès būklès atsigavimo kaita ir treniruotumo lygis dažniausiai vertinamas pagal iprastus funkcinius rodiklius (širdies susitraukimų dažni), kurie parodo reguliuojančios sistemos ypatumus, tačiau juk metabolinio atsigavimo ir širdies veiklos normalizavimosi tempai nèra visiškai tokie pat. Vadinasi, tik pagal širdies susitraukimu dažni nustatyti fizinio krūvio ribas, kaip iprasta profesionaliajame sporte, ne visada tikslu (Gocentas, Andziulis, 2004).

Paskutiniais metais atlikta daug tyrimu, nagrinejjančių kompleksinį fizinio krūvio poveikị organizmui. Noredami nuodugniau ištirti sportininku atsigavimo po dozuoto fizinio krūvio kaitą, taikème integralios organizmo reakcijos į fizini krūvi modeli (Vainoras, 1996; Vainoras, 2002; Poderys, 2004), kuris apima reguliacinès (centrinès nervu sistemos, autonominio, humoralinio valdymo), aprūpinančiosios (kvèpavimo, širdies ir kraujagyslių) ir vykdančiosios (fizinio krūvio metu veikliu raumenų grupių) sistemų tarpusavio sąsają ir ju poreiški krūvio metu. Remiantis šiuo modeliu nagrinèti nesportuojančiu ir sveikatingumo grupes lankančių vyrų ir moterų (Šilanskienè, 2003), taip pat moterų, lankančiu dvejopo pobūdžio fizinio krūvio (lokalieji pratimai, skirti atskiru raumenu grupių funkciniam pajègumui didinti, arba aerobiniai acikliniai pratimai) sveikatingumo pratybas, organizmo atsigavimo rodikliai (Vitartaite ir kt., 2004). Nagrinejjome krepšininkų, futbolininkų ir nesportuojančiuju atsigavimo proceso ypatumus po submaksimalaus fizinio krūvio mėginio, tyrẻme minètų sistemų atsigavimo pusperiodžius ir stabilumą (Žumbakytė ir kt., 2003; Kajënienė ir kt., 2002; Žumbakytė ir kt., 2006). Šio tyrimo metu nuodugniau nagrinejame atsigavimo metu vykstančius procesus.

Tyrimo tikslas - ištirti krepšininkų, futbolininkų, nesportuojančiu asmenų (vyru ir moterų) organizmo atsigavimą rodančių fiziologiniu rodiklių pokyčio dydžius kiekvieną atsigavimo minutę po submaksimalaus fizinio krūvio ir juos palyginti.

\section{METODIKA}

Buvo tirta 270 asmenų. Tiriamieji suskirstyti i grupes pagal lytị ir sporto šaką. Iširtos trys vyru krepšininkų (KV), futbolininku (FV), nesportuojančiujų (NV) ir dvi moterų krepšininkiu (KM) ir nesportuojančiujų (NM) grupès. Nagrinètų grupių apibūdinimas pateiktas lentelèje.

Naudota KMU Kardiologijos institute sukurta automatizuota EKG analizès sistema „Kaunas-Krūvis“, kuri sinchroniškai registruoja ir analizuoja raumenu išugdomą galingumą, arterini kraujo spaudimą ir EKG (Vainoras, 1996). Atliktas visų tiriamuju kompiuterizuotas veloergometrinis fizinio krūvio mèginys naudojant trumpalaiki provokacini tyrimo protokolą (Vainoras, Jaruševičius, 1996). Sveikos nesportuojančios moterys krūvi pradejjo nuo $50 \mathrm{~W}$ galingumo ir kas minute ji didino po $25 \mathrm{~W}$ iki submaksimalaus $(50+25 \mathrm{n} \mathrm{W})$ (submaksimalus galimas, bet nebūtinas galingumas - ribojamas pasireiškus klinikiniams požymiams). Vyrai ir krepšininkès krūvi pradejjo atlikti nuo $50 \mathrm{~W}$ galingumo ir kas minute ji didino po $50 \mathrm{~W}$ iki submaksimalaus išugdomo $(50+50 \mathrm{n} \mathrm{W})$. Atsigavimo laikotarpio rodikliai registruoti penkias minutes. Veloergometrinio tyrimo metu buvo registruojami tarpusavyje susijusių kelių pagrindinių organizmo sistemų, t. y. vykdančiosios (periferijos), aprūpinančiosios ir reguliacinès sistemu rodikliai. Vertintos tiek pavienès, tiek integruotos minètu sistemų funkcijos. Nagrinèti širdies dažnio (HR), intervalo JT (elektrokardiogramoje nuo jungties taško $\mathrm{J}$ iki $\mathrm{T}$ bangos pabaigos) (JT), sistolinio kraujo spaudimo (S) ir išvestinių dydžių, tokių kaip santykinès repoliarizacijos JT / RR, t. y. (JT / RR), bei santykinès pulsinès amplitudès (S-D) / S) (čia D - diasolinis kraujo spaudimas) 
pokyčiai kiekvieną atsigavimo minutę. Pokytis apskaičiuotas procentais pagal formulę:

$$
\mathrm{X}=100\left(\mathrm{X}_{\mathrm{N}}-\mathrm{X}_{(\mathrm{N}+1)}\right) /\left(\mathrm{X}_{\max }-\mathrm{X}_{0}\right) \text {, }
$$

čia X - ieškomas dydis (tiriamojo rodiklio pokytis), $X_{n}$ - dydis vertinamą minutę, $X_{(n+1)}-$ dydis ateinančią minutę, $X_{\max }$ - dydis maksimalaus krūvio metu, $\mathrm{X}_{0}$ - dydis prieš krūvị.

Rodikliai S ir HR labiau sietini su reguliacija, o (S-D) / S ir JT - su atskiru organu funkcija ir nusako periferijos atsaka.

Pagal Stjudento $t$ kriterijų (lyginant tiriamuju amžiu, ūgi, kūno svori, santykini atlikto darbo galingumą) apskaičiuotas aritmetinis vidurkis, vidutinis standartinis nuokrypis ir nepriklausomų imčių vidurkio skirtumų reikšmingumas. Procentais išreikštų duomenu vidurkiams palyginti naudotas Mann-Whitney-Wilcoxon Z kriterijus, taikytas nepriklausomoms imtims. Vidurkių skirtumas laikytas patikimu, jei paklaidos tikimybè mažesnè nei 0,05 . Santykiui tarp atskirų sistemų nusakyti apskaičiuotas Spirmeno koreliacijos koeficientas ir įvertintas jo reikšmingumas.

\section{REZULTATAI}

Statistiškai patikimas skirtumas nustatytas tik per pirmas tris atsigavimo minutes. Pirmą atsigavimo minutę (1 pav.) visose tirtose grupèse labiausiai kinta JT / RR. Jos kitimo dydis patikimai didesnis nei kiti tirti kitimo dydžiai $(\mathrm{p}<0,05)$. Visose grupèse taip pat patikimai skyrèsi HR pokytis $(\mathrm{p}<0,05)$. Jis buvo mažesnis nei JT / RR pokytis, tačiau didesnis nei S, JT ar $(\mathrm{S}-\mathrm{D}) / \mathrm{S}$ pokytis. Labai ryškiai skyrèsi visų tirtų grupių periferijos atsako - santykinès pulsinès amplitudès - pokyčio reikšmès (buvo neigiamos). Vadinasi, pirmą atsigavimo minutę santykinè pulsinè amplitude kitaip nei kiti tirtieji rodikliai didejo, o ne mažejo. S ir JT pokytis užèmé tarpinę vietą tarp HR bei (S-D) / S ir nesiskyre KM, KV bei NV grupèse. NM ir FV grupėse $\mathrm{S}$ pokytis buvo patikimai didesnis nei JT $(p<0,05)$.

Lyginant grupių rodiklių skirtumą nustatyta, kad HR / JT pokytis KV grupeje buvo didesnis nei KM grupeje, NV grupeje didesnis nei NM, KV ir $\mathrm{NV}$ grupèse, lyginant su FV grupe $(\mathrm{p}<0,05)$. HR pokytis patikimai didesnis $\mathrm{KV}$ grupeje, lyginant su KM grupe, NV grupeje - lyginant su NM ir KV - lyginant su FV grupe $(p<0,05)$. JT kitimo greitis buvo didesnis NV grupeje, lyginant su NM, o NV - lyginant su KV ir FV grupèmis $(\mathrm{p}<0,05)$.

Patikimas vidutinio stiprumo ryšys $(\mathrm{r}=0,465$, $\mathrm{r}=0,496, \mathrm{r}=0, \mathrm{r}=0,465, \mathrm{r}=0,662)$ nustatytas tarp JT ir HR futbolininkų, krepšininkų, nesportuojančių moterų bei nesportuojančių vyru grupèse.

Antrą atsigavimo minutę vienodo visų tirtų grupių rodikliu pokyčio (kaip pirmą minutę) neužregistruota (2 pav.). Šiuo laikotarpiu labiausiai kinta periferijos rodikliai. NM, KV, NV ir FV grupèse užregistruoti didžiausi santykinès pulsinès amplitudès pokyčiai, tačiau nuo kitų tirtų rodikliu pokyčio vidurkių jie skyrèsi tik NM ir $\mathrm{NV}$ grupèse. KV ir FV grupeje jie nesiskyrè nuo $\mathrm{S}$ bei JT pokyčio vidurkių. Išsiskyrè krepšininkių grupè, kurioje užregistruotas didžiausias JT rodiklio pokytis, o kitų tirtų rodiklių vidurkiai nesiskyrè.
1 pav. Fiziologinių rodiklių pokytis pirmą atsigavimo minutę po submaksimalaus fizinio krūvio

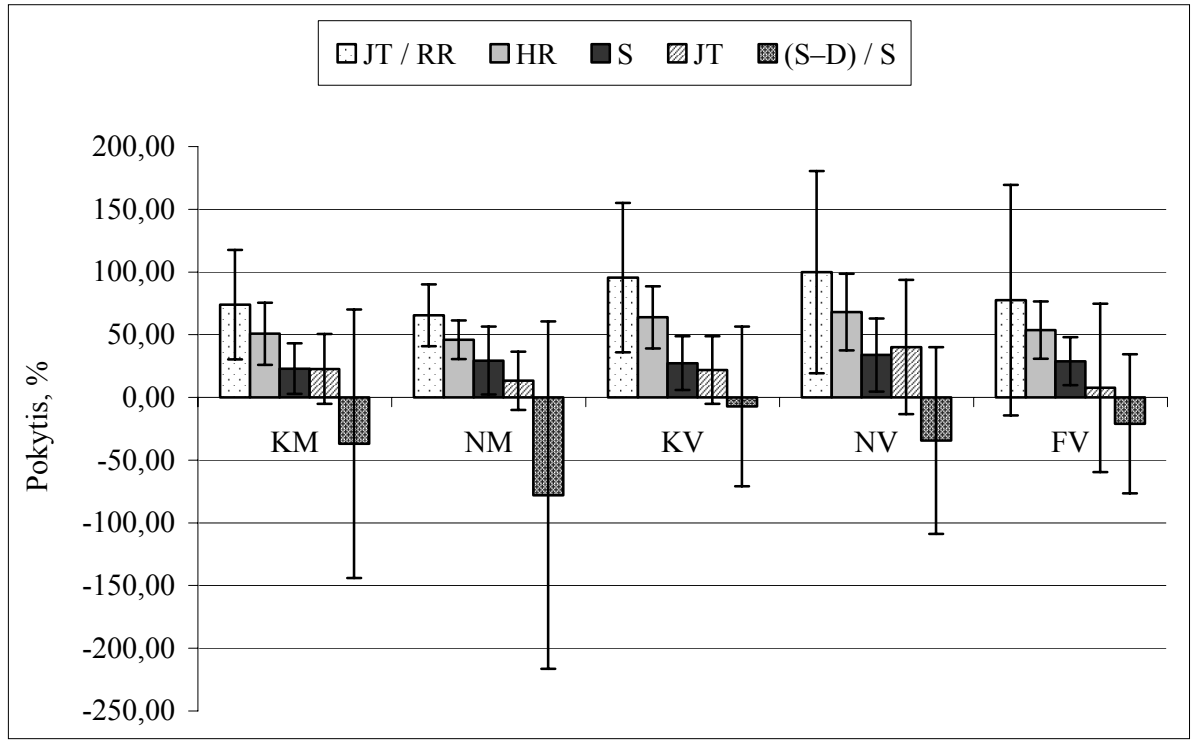




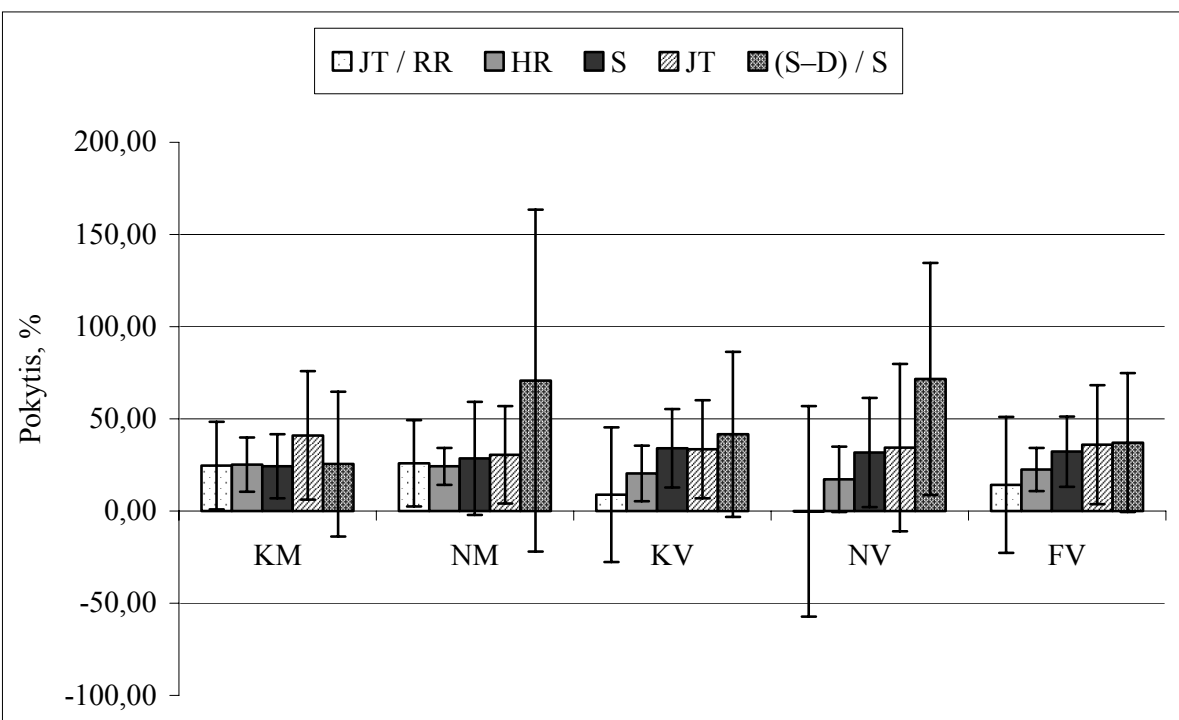

2 pav. Fiziologinių rodiklių pokytis antrą atsigavimo minutę po submaksimalaus fizinio krūvio

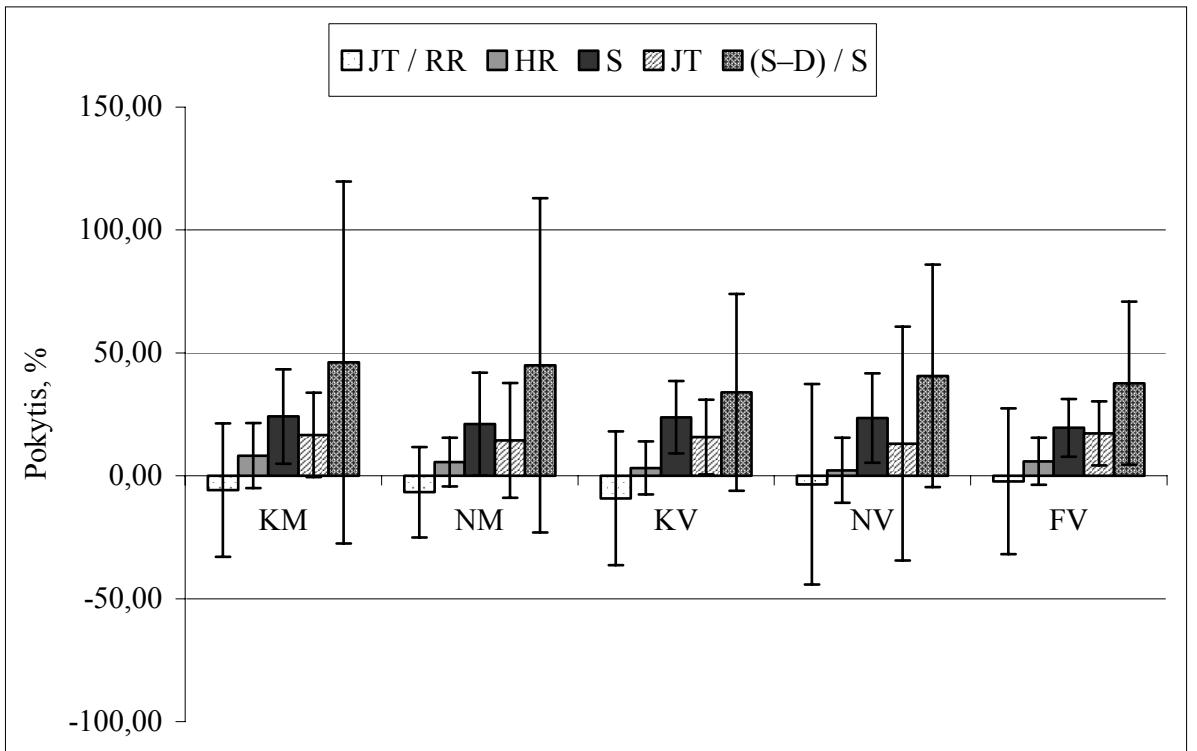

3 pav. Fiziologinių rodiklių pokytis trečią atsigavimo minutę po submaksimalaus fizinio krūvio

Lyginant pokyčio dydžius tarp grupių, nustatytas didesnis JT / RR kitimas KM nei KV grupeje, taip pat $\mathrm{NM}$ - nei NV ir FV - nei NV $(\mathrm{p}<0,05)$. HR pokytis NM grupeje buvo didesnis nei NV grupeje, o FV - nei NV $(\mathrm{p}<0,05)$. JT pokytis tirtose grupèse patikimai nesiskyrè. KV grupeje S pokytis buvo didesnis nei KM $(\mathrm{p}<0,05)$. $(\mathrm{S}-\mathrm{D}) / \mathrm{S}$ pokytis didesnis $\mathrm{MN}$ nei $\mathrm{KM}$ grupejje, NV - nei KV, FV ir KV grupejje nei KM $(\mathrm{p}<0,05)$. Kitų statistiškai patikimų tirtų rodiklių pokyčio skirtumų antrą atsigavimo minutę po fizinio krūvio neužregistruota.

Antrą atsigavimo minutę nustatytas reikšmingas koreliacinis ryšys tarp HR ir JT $(r=0,553$, $r=0,227, r=0,389)$ futbolininku, krepšininku ir nesportuojančiu moteru grupèse.

Trečią atsigavimo minutę nustatyti visu tirtų grupių periferijos rodiklių pokyčiai (3 pav.).
Visose tirtose grupėse užregistruotas didžiausias (S-D) / S pokytis, jis patikimai skyrèsi nuo HR, JT, S ir JT / RR pokyčio $(\mathrm{p}<0,05)$. Taip pat išsiskyrė JT / RR pokytis. Visose tirtose grupèse jis buvo neigiamas ir patikimai skyrèsi nuo visu tirtu rodiklių. HR pokytis visose tirtose grupèse buvo didesnis už JT / RR ir mažesnis už JT pokyti $(p<0,05)$. S ir JT pokytis KM, NM ir FV grupèse nesiskyre, $\mathrm{KV}$ ir $\mathrm{NV}$ grupèse $\mathrm{S}$ jis buvo patikimai didesnis nei JT pokytis $(\mathrm{p}<0,05)$.

Lyginant pokyčio dydžius tarp grupių, nustatytas didesnis JT / RR pokytis KV grupeje nei KF grupeje ir didesnis HR pokytis KM nei KV grupèje $(\mathrm{p}<0,05)$.

Trečią atsigavimo minutę nustatytas patikimas koreliacinis ryšys tarp JT ir HR $(r=0,237$, $\mathrm{r}=0,355, \mathrm{r}=0,506)$ krepšininkų vyrų ir moteru, nesportuojančių moterų grupèse. 


\section{REZULTATŲ APTARIMAS}

Kaip nurodo A. Gocentas ir A. Andziulis (2004), didžioji atsigavimo proceso dalis ivvyksta per pirmas dvi tris minutes. M. Javorka, I. Zila, T. Balharek ir kt. (2002) užregistravo staigu eksponentini HR dydžio mažejjimą per pirmas dvi poilsio minutes po submaksimalaus fizinio krūvio, vèliau šis rodiklis mažèjo tolygiai ir lètai. Tarp mūsų tirtų rodiklių statistiškai patikimas skirtumas užregistruotas tik per pirmas tris minutes. Vertindami fiziologinių rodiklių atsigavimo dydžiu pokyčius kiekvieną atsigavimo minutę pastebejome, kad visose tirtose grupèse greičiausiai atsigauna reguliacinès ir aprūpinančiosios sistemų ryšys (JT / RR). Pirmą atsigavimo minutę jis kinta nuo 60,46 iki 99,8\% visose tirtose grupèse. Antrą minutę šio rodiklio pokytis yra daug mažesnis ir trečią minutę jau igauna neigiamą reikšmę. Raumenyse pirmą minutę vyksta priešingi pokyčiai. Santykinè pulsinè amplitudè didejja pirmą minutę, o antrą, trečią ima mažèti ir igauna maksimalias kitimo reikšmes. Reguliacinès ir aprūpinančiosios sistemų pokyčiai užima tarpinę poziciją ir skiriasi tarp grupių. Š̉ atsigavimų eiliškumą lemia fiziologiniai procesai. Didžiausią darbą atlikusiems raumenims atsigauti reikia daugiausia laiko, tuo tarpu greitas reguliacinès ir aprūpinančiosios sistemos ryšio atsigavimas, ko gero, leidžia išnaudotiems rezervams tolygiau mobilizuoti būsimų reguliacinès, aprūpinančiosios sistemų ir galiausiai periferijos pokyčius. Panaši šių rodiklių atsigavimo seka aprašyta ir anksčiau spausdintuose mūsų straipsniuose. Tuomet tyrème tų pačių rodiklių atsigavimo pusperiodžius ir jų stabilumą. Panaši šių fiziologinių rodiklių atsigavimo pusperiodžiu seka nustatyta ir tarp nesportuojančiujuc (Šilanskienè, 2003), moterų, lankančių dvejopo pobūdžio fizinio krūvio pratybas (Vitartaite ir kt., 2004), tarp krepšininkiu ir nesportuojančių moterų (Žumbakytė ir kt., 2003). Neaktyvaus atsigavimo metu po dinaminio fizinio krūvio staigu HR sumažejimą sukelia centrinès nervu sistemos impulsacija (Carter et al., 1999). Vèlesnius pokyčius sukelia metaboreceptorių, baroreceptoriu stimuliacija, katecholaminų ir susikaupusios šilumos pašalinimo reakcija (Carter et al., 1999; Nishime et al., 2000).

Tyrimo metu nustatyta, kad greičiau kinta vyrų nei moteru JT / RR. Pirmą atsigavimo minutę šio rodiklio pokytis didesnis tarp nesportuojančiu vyrų ir krepšininkų, antrą — tarp nesportuojančių moterų ir krepšininkių, trečią minutę šio skirtumo nebepastebima. Identiški ir HR kitimo greičio dèsningumai. Ši skirtumą esame užregistravę anksčiau (Žumbakyte ir kt., 2006) ir manème, kad tai atsitinka dèl skirtingo santykinio atlikto darbo galingumo nesportuojančiu vyru, nesportuojančiu moteru grupèse. Toks paaiškinimas atliekant ši tyrimą netenka prasmès, nes tiek krepšininkų, tiek nesportuojančių vyru ir moteru grupių santykinio darbo galingumo rodikliai nesiskyrè. Taip pat lieka neaišku, kodèl nesportuojančių vyrų JT intervalas pirmą atsigavimo minutę kinta greičiau nei nesportuojančių moterų. Šis skirtumas tarp krepšininkų neužregistruotas.

Skyrèsi sportuojančiu ir nesportuojančių moteru sistolinio kraujo spaudimo kitimo greitis. Antrą atsigavimo minutę jis kur kas greičiau kito nesportuojančiu moteru grupejje. Tai gali atsitikti dèl didesnès reguliacinių sistemų apkrovos išugdžius didesni fizinio darbo galingumą (krepšininkių santykinis atlikto darbo galingumas patikimai didesnis $(\mathrm{p}<0,05)$ nei nesportuojančiu moterų). Ši teigini patvirtina ir reikšmingas koreliacinis ryšys tarp santykinio atlikto darbo galingumo ir sistolinio kraujo spaudimo pokyčio antrą atsigavimo minutę tiek krepšininkių, tiek nesportuojančiu moteru grupèse $(r=-0,327$ ir $r=-0,402$ atitinkamai). E. Grinienè, Ž. Kačiulytė, R. Žumbakytè ir kt. (2005) pastebėjo greitesni krepšininkių nei nesportuojančių moterų $\mathrm{S}$ atsigavimą, kai atlikto darbo galingumas nesiskyrè. Tokio patikimo skirtumo tarp nesportuojančių vyru, krepšininku ir futbolininkų nenustatėme, nors krepšininkų ir futbolininku santykinis atlikto darbo galingumas buvo patikimai didesnis.

Skirtingą periferijos atsaką sportuojančių ir nesportuojančių tiriamuju grupèse galèjo lemti nevienodas treniruotumas, fizinio krūvio trukmè ir pobūdis (Gocentas, Andziulis, 2004). Santykinès pulsinès amplitudès pokyčiai kur kas didesni pirmą ir antrą minutę tarp nesportuojančių moteru (lyginant su krepšininkèmis) ir antrą - tarp nesportuojančių vyrų (lyginant su krepšininkais ir futbolininkais). Skirtumą tarp futbolininkų ir krepšininkų šių rodikliu pokyčio galejjo lemti nevienodas sportinis stažas $(\mathrm{p}<0,05)$, nors patikimo koreliacinio ryšio tarp sportinio stažo ir tirtu fiziologinių rodiklių pokyčio nenustatyta.

G. Jaruševičius (2000) tyrè JT intervalo trukmès ir HR priklausomybę ramybès bei maksimalaus fizinio krūvio metu. Nustatyta labai stipri $(r>0,7)$ ir stipri $(0,5<\mathrm{r}<0,7)$ neigiama 
koreliacija ramybės metu, t. y. didejant HR, JT trumpèjo ir, atvirkščiai, mažejjant HR, JT trukmè ilgejjo. Maksimalaus fizinio krūvio metu sveiku asmenu grupeje nustatyta tik vidutinè $(\mathrm{r}=-0,38)$ JT intervalo priklausomybè nuo HR, o sportuojančiuju — stipri koreliacija $(r=-0,56)$. Atlikto tyrimo metu atsigavimo po krūvio laikotarpiu užregistruotas patikimas koreliacinis ryšys tarp šių rodikliu kitimo greičių beveik visose tirtose grupèse. A. Šilanskiené (2003), vertinusi HR ir JT intervalo pokyčius krūvio metu fazinèje plokštumoje, nustatė, kad tarp šių rodiklių nèra tiesinès priklausomybès ir kad tarp lyčiu visose amžiaus grupèse yra reikšmingas JT intervalo kitimo skirtumas. Ji teigia, kad fizinis aktyvumas veikia tiek nagrinėtų HR ir JT rodiklius, tiek ju kitimo greičius.

Šiame straipsnyje nenagrinejjome tiriamuju antropometriniu duomenu poveikio atsigavimo procesams. Tai tolesnių mūsų tyrimų objektas.

\section{IŠVADOS}

1. Skirtingi atsigavimo rodikliai patikimai skiriasi atsigavimo greičiu.

2. Futbolininkų, krepšininkų, nesportuojančiujų, vyrų ir moterų atskirų fiziologinių procesų atsigavimo greičiai bei jų seka skiriasi.

\section{LITERATŪRA}

Carter, R., Watenpaugh, D. E., Wasmund, W. L. et al. (1999). Muscle pump and central command during recovery from exercise in humans. Journal of Applied Physio$\log y, 87,1463-1469$.

Glaister, M. (2005). Multiple sprint work. Physiological responses, mechanisms of fatigue and the influence of aerobic fitness. Sports Medicine, 35 (9), 757-777.

Gocentas, A., Andziulis, A. (2004). Krepšininkų organizmo deguonies sunaudojimo pokyčiai atsigavimo metu. Medicina (Kaunas), 40 (6), 569-573.

Grinienè, E., Kačiulytè, Ž., Žumbakytè, R. ir kt. (2005) Functional and mental working abilities for female after physical load. Medicina (Kaunas), 41 (4), 767-773.

Jaruševičius, G. (2000). Išeminès širdies ligos požymiu fizinio krūvio metu paieška ir ùvertinimas pagal vainikiniu arteriju pažeidimo vieta: daktaro disertacija. Kaunas: KMU.

Javorka, M., Zila, I., Balharek, T. et al. (2002). Heart rate recovery after exercise: Relations to heart rate variability and complexity. Brazillian Journal of Medical and Biological Research, 35, 991-1000.

Kajènienè, A., Vainoras, A., Žumbakytè, R. ir kt. (2002). Dozuoto fizinio krūvio méginio atsigavimo laikotarpio fiziologiniu parametru vertinimas. Biomedicinine inžinerija: tarptautinès konferencijos pranešimu medžiaga (pp. 147-150). Kaunas: Technologija.

Nishime, E., Cole, C., Blackstone, E. et al. (2000). Heart rate recovery and treadmill exercise score as predictors of mortality in patients referred for exercise ECG. Journal of the American Medical Association, 284, 1392-1398.

Poderys, J. (2004). Kineziologijos pagrindai: mokomoji knyga. Kaunas.

Šilanskienè, A. (2003). Žmogaus organizmo funkcinès būkles kitimo ilgalaikiu treniruočiu metu vertinimas: daktaro disertacija. Kaunas: KMU.
Vainoras, A. (1996). Investigation of the heart repolarization process during rest and bicycle ergometry (100-lead and standard 12-lead ECG data): Synopsis Doctor of Science Habil. Thesis. Kaunas.

Vainoras, A., Jaruševičius, G. (1996). Veloergometrija: mokymo metodine priemone. Kaunas. P. 2-3.

Vitartaitè, A., Vainoras, A., Sendžikaitè, E. (2004). Moteru atsigavimo po fizinio krūvio fiziologiniu parametru ypatumai. Biomedicinine inžinerija: tarptautinès konferencijos pranešimu medžiaga (pp. 62-65). Kaunas: Technologija.

Wasserman, K., Hansen, J. E., Sue, D. Y. et al. (1988). Principles of Exercise Testing and Interpretation. 3rd ed. Philadelphia: Lippincott Williams \& Wilkins.

Žumbakytè, R., Kajènienè, A., Vainoras, A. (2003). Computerized evaluation of recovery phase in women after bicycle test. International Journal of Computer Science in Sport, Vol. 2, Edition 1, 196-198. Prieiga per interneta: URL:http://www.iacss.org.

Žumbakytė, R., Vainoras, A., Kajènienè, A. ir kt. (2006). Krepšininkų, futbolininkų ir nesportuojančiujų atsigavimo proceso ypatybès po submaksimalaus fizinio krūvio mèginio. Ugdymas. Küno kultūra. Sportas, 3 (62), 59-64. 


\title{
ASSESSMENT OF ALTERATIONS IN THE PARAMETERS THAT CHARACTERIZE THE FUNCTIONAL CONDITION OF HUMAN ORGANISM OF BASKETBALL AND SOCCER PLAYERS AFTER BICYCLE STRESS TEST
}

\author{
Alma Kajèniené $\dot{e}^{1,2}$, Alfonsas Vainoras ${ }^{2}$, Renata Žumbakyte் $\dot{\mathrm{C}}^{1,2,3}$, Kristina Berškiene் $\dot{\mathrm{e}}^{2,3}$ \\ Lithuanian Academy of Physical Education ${ }^{1}$, Kaunas University of Medicine ${ }^{2}$, \\ Kaunas University of Technology ${ }^{3}$, Kaunas, Lithuania
}

\begin{abstract}
The aim of study was to investigate the changes in parameters that characterize the functional condition of human organism of basketball, soccer players and persons without sport activity at every minute of recovery process.

Two groups of women were investigated: BW group - 38 basketball players, NW group -32 person without sport activity and 3 groups of men: BW group - 113 basketball players, FM group -55 soccer players, NM group - 32 persons without sport activity.

There are a lot of situations when we need to evaluate features of organism reactions to load. According to physiologic changes in human organism during load, the main systems responsible for the functioning of the organism could be working muscles, cardiovascular system is responsible for the energy supply, lungs - for oxygen supply, and the coordination all those systems functioning together is the regulatory system. Two responsible supply systems - cardiovascular and respiratory systems - could be joined into one supplying system.

"Kaunas-Load", an automatized ECG analysis system, created at the Institute of Cardiology of Kaunas University of Medicine, that is capable of both registering and analyzing the power developed by the subject, 12 leads of ECG and arterial blood pressure synchronically, has been used for evaluating the functional condition of the human body. The subject did a computer-based bicycle ergometry test. A shortterm provocative protocol was used. The initial power of the load applied to everybody was $50 \mathrm{~W}$ and it was increased for healthy NW by $25 \mathrm{~W}$ every minute, and by $50 \mathrm{~W}$ for others till submaximum power developed.

Changes of systolic arterial blood pressure $-\mathrm{S}$, heart rate $-\mathrm{HR}$, JT interval $-\mathrm{JT}$, ratio of interval JT and RR - JT / RR, ratio of pulse amplitude and systolic arterial blood pressure - (S-D) / S were estimated every minute of recovery. The duration of the recovery process was five minutes.

Research results suggest the following conclusions: 1. Investigated functional parameters had the different recovery speed. 2 . The dynamics of recovery was different in the investigated groups.
\end{abstract}

Keywords: electrocardiogram changes, load, recovery. 